\title{
Evaluation of the partial renewal of in situ phytoplankton microcosms and application to the impact assessment of bentazon and dimethenamid
}

\author{
Denis de la Broise ${ }^{1,{ }^{*}}$, Sabine Stachowski-Haberkorn ${ }^{2}$
}

\author{
${ }^{1}$ LEMAR, IUEM, UEB, Université de Bretagne Occidentale, rue Dumont d'Urville, 29280 Plouzané, France \\ 2 IFREMER Laboratoire d'Écotoxicologie, rue de l'île d'Yeu, BP 21105, 44311 Nantes cedex, France \\ *: Corresponding author : Denis de la Broise, email address : denis.de-labroise@univ-brest.fr \\ Tel: +330298498623 Fax: +330290944818
}

\begin{abstract}
:
Microcosms, each consisting of $2 \mathrm{~L}$ natural surface seawater maintained in 2.3- $\mathrm{L}$ glass bottles, were immersed at a depth of 6 metres. The renewal of ten percent of microcosm volumes was carried out every other day. Phytoplankton-containing seawater was used for renewal (previously filtered through 25-, 50- or 200- $\mu \mathrm{m}$ cut-off). Phytoplankton community pigment analysis (by HPLC) and flow cytometry analysis were performed. After 13 days, data exhibited phytoplankton characteristics in microcosms in the same range as that of the natural surrounding sea water over the same period. Furthermore, in these microcosms, a negative correlation was observed between the filtration cut-off used for renewal water, and the eukaryote cell count. Herbicides were tested as commercial mixtures at 1, 10 and 100 $\mu$ g.L-1 active principal. Both Frontier ${ }^{\circledR}$ (dimethenamid) and Basamais ${ }^{\circledR}$ (bentazon) induced significant modifications of the phytoplankton populations at every concentration tested. Such results suggest a possible disturbance in polluted coastal areas.
\end{abstract}

Keywords: phytoplankton; microcosm; herbicides; dimethenamid; bentazon

\section{Introduction}


Pesticides are in widespread use, especially in intensive agriculture, but induce environmental hazards such as acute or chronic contamination of aquatic biota via spray drift, leaching or run-off from treated areas. In estuarine and coastal areas, herbicides have been reported at concentrations ranging from ng. $\mathrm{L}^{-1}$ to $\mu$ g. $\mathrm{L}^{-1}$ (Chesworth et al. 2001; Steen et al. 2001; Oros et al. 2003; Burgeot et al. 2007; Lewis et al. 2009; Añasco et al. 2010). These contaminants can negatively impact non-target organisms including phytoplankton, which are potentially vulnerable to herbicides due to their physiological similarities to terrestrial plants (DeLorenzo et al. 2001; Dorigo et al. 2004). The impact of herbicides on phytoplankton communities could seriously damage ecosystem function, as these primary producers are vital for nutrient transfer to higher trophic levels.

Phytoplankton toxicity assessments are usually run using monospecific microalgal bioassays in controlled laboratory conditions. Many such studies have been conducted on pesticides (Rioboo et al. 2002; DeLorenzo et al. 2004; Weiner et al. 2004; Gatidou and Thomaidis 2007; Santin-Montanya et al. 2007; Galhano et al. 2009; Prado et al. 2009; Magnusson et al. 2010), but the sensitivity threshold in such tests is highly dependent on the species tested (Cairns 1986). Furthermore, Bérard et al. (1999) demonstrated that single-species tests may fail to predict indirect or system responses, such as changes in the population distribution over time. Therefore, studies focusing on the whole natural community, based on biological parameters measured at the community level, provide more reliable predictions about pesticide safety in aquatic environments (Barry and Logan 1998; Bérard et al. 1999).

The impact of toxicity on natural communities can be assessed in several ways: by sampling at different natural sites and/or times to look for pollution-related characteristics (Kostanjšek et al. 2005; Pesce et al. 2008), by sampling natural communities from the field and maintaining them in microcosms under controlled laboratory conditions (DeLorenzo et al. 1999b; Seguin et al. 2001), or by conducting studies using in situ microcosms. We recently showed that such microcosms immersed in "average water column conditions", with partial water renewal, can be considered as good experimental models for natural nano- and picophytoplankton from coastal waters (de la Broise and Palenik 2007). Such in situ micro- or mesocosm experiments offer the best aspects of both laboratory and open field systems, as this experimental set-up allows the testing of multiple replicates in ecologically realistic conditions (Van den Brink et al. 2002). Microcosms set up in natural environments allow a wider species spectrum to be tested, including populations that are difficult to maintain $e x$ 
situ, and can thus permit a wider survey of the susceptibility of the microbial community to toxicants (Yasuno et al. 1993). Seguin et al. (2001) and Leboulanger et al. (2001) pointed out the need for such microcosm systems in order to obtain reliable toxicity data. In the present study, we chose to develop small-volume high throughput in situ microcosms, allowing routine testing of several substances, using up to 108 microcosms simultaneously.

The aims of the present study were to:

- Investigate the need for partial renewal in microcosms;

- Compare microcosms with the natural surrounding surface water to evaluate whether they support communities that are representative of the surrounding environment;

- Validate the microcosm experimental system for the impact assessment of herbicides on natural phytoplankton communities.

Pigment fingerprints are one of the tools that can be used to provide an overall view of phytoplankton communities, as their profiles are related to community composition. They are obtained from High performance liquid chromatography (HPLC) analysis and can be applied in studies dealing with environmental diagnoses (Sherrard et al. 2006), as well as in ecotoxicological studies to assess the effects of pesticides on the phytoplankton community (Dorigo et al. 2004; Readman et al. 2004; Devilla et al. 2005; Stachowski-Haberkorn et al. 2009).

Flow cytometry can also provide information about the distribution and abundance of natural photosynthetic populations (Marie et al. 1999; Rutten et al. 2005). Toxicity assessment using flow cytometry has been used both in studies based on phytoplankton cultures (Lage et al. 2001; Stauber et al. 2005; Yu et al. 2007) and those examining natural photosynthetic communities (Readman et al. 2004; Zamora-Ley et al. 2006; de la Broise and Palenik 2007; Stachowski-Haberkorn et al. 2008, 2009).

These two complementary techniques were combined in our sample analysis to increase the sensitivity with which we could compare phytoplankton communities.

\section{Materials and Methods}

A set of microcosms in bottles containing filtered surface seawater was placed in situ and their contents partially replaced every two days during experiments. We designed the experiments to test: i) the role of filtration cut-off level used on the renewal water and ii) the impacts of Basamaïs ${ }^{\circledR}$ and Frontier®, on marine phytoplankton communities. 
Chlorophyll $a(\mathrm{Chl} a)$ measurements and pigment fingerprints were obtained from biomass collected on filters, and microcosm subsamples were also analysed using flow cytometry.

\subsection{Microcosm apparatus}

The outdoor experiments were conducted from mid June to early August 2006, in Port-la-

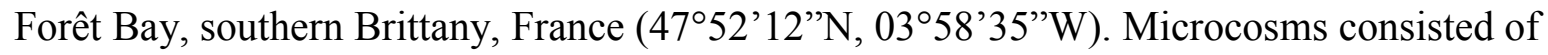
hermetically sealed 2.3-L glass bottles. These bottles were filled with $2 \mathrm{~L}$ of $200-\mu \mathrm{m}$ filtered fresh seawater from the surface layer at the field site, containing natural zooplankton and phytoplankton communities, enclosed with about $300 \mathrm{~mL}$ of air (de la Broise and Palenik 2007). Thirty-six microcosms were installed on a 3-m diameter circular stainless-steel frame (a "wheel") that was anchored to the sea floor with a $400 \mathrm{~kg}$ concrete block, and suspended from a surface buoy allowing the bottles to remain at $6 \mathrm{~m}$ depth (average mid-depth of the water column), regardless of the tide (Stachowski-Haberkorn et al. 2008). Every other day, the wheel was hoisted out of the water and positioned so that it encircled the boat (Fig. 1), allowing bottle handling and partial medium renewal. Three wheels with microcosms were installed for the summer.

\subsection{Renewal experiment}

Microcosms were managed according to two protocols: either with no water renewal (control), or a $10 \%$ renewal $(200 \mathrm{~mL})$ every other day, using ambient seawater filtered through mesh of different sizes: $0.22,25,50$ and $200 \mu \mathrm{m}$. Thirty microcosms were prepared: six replicates for each of the five treatments. Replicate microcosm bottles were distributed all around the frame (one from each of the five treatments in succession). The experiment was continued for 13 days. On the first, fourth and last days of experiment, five samples of surrounding surface seawater (2 L) were also collected for analysis.

\subsection{Herbicide assessment}

\subsubsection{Herbicides}

The herbicides tested in this study are the commercial formulations of bentazon (Basamaïs ${ }^{\circ}$, BASF) and dimethenamid (Frontier®, BASF). Concentration values represent those of the pure active substances. The herbicide stock solutions $(10 \mathrm{mg} / \mathrm{L}$ bentazon and $10 \mathrm{mg} / \mathrm{L}$ dimethenamid) were prepared in $0.22-\mu \mathrm{m}$ filtered seawater, previously autoclaved for $20 \mathrm{~min}$ at $121^{\circ} \mathrm{C}$. After agitation for $48 \mathrm{~h}$ using a magnetic stirrer, the solutions were kept at $-24^{\circ} \mathrm{C}$. 
Freshly thawed stock solutions were added directly into the microcosm bottles just before immersion. Herbicide concentrations were analyzed on pooled water samples from all the replicate bottles of each treatment, collected on the last day of the experiment. Samples were frozen until analysis.

Herbicide analyses were performed by the IDHESA Laboratory (Brest, France), using on-line solid-phase extraction coupled with liquid chromatography and electrospray ionisationtandem mass spectrometry (Waters 2690 HPLC Separation Module; Waters 996 Photodiode Array Detector; Micromass ${ }^{\circledR}$ Quattro Ultima ${ }^{\mathrm{TM}}$ Mass Spectrometer). The detection limit was $0.005 \mu \mathrm{g} \cdot \mathrm{L}^{-1}$.

\subsubsection{Herbicide experiments}

An experiment was carried out for each herbicide. In both cases, twenty microcosms were prepared: five replicates for control and five for each of the three concentrations tested (1 $\mu \mathrm{g} . \mathrm{L}^{-1}, 10 \mu \mathrm{g} . \mathrm{L}^{-1}$ and $\left.100 \mu \mathrm{g} . \mathrm{L}^{-1}\right)$. Replicate microcosm bottles were distributed all around the frame (one from each of the four treatments in succession).

Every other day, the frame was hauled out of the water and $10 \%(200 \mathrm{~mL})$ of the $2 \mathrm{~L}$ seawater in each bottle was collected in a tank for proper disposal, and then replaced with the same volume of fresh $200-\mu \mathrm{m}$ filtered surrounding seawater, before re-immersing the frame. All the bottles were finally collected for analyses on the last day. They were kept protected from the light in plastic boxes, under white PVC sheets, until treatment.

\subsection{Analyses}

From each microcosm or surrounding seawater sample, $1 \mathrm{~L}$ water was filtered through 0.22 $\mu \mathrm{m}$ polysulfone filters. The filters were then stored at $-80^{\circ} \mathrm{C}$ until pigment analysis using HPLC. For cytometry analyses, samples $(1.5 \mathrm{~mL})$ were dropped into cryotubes and fixed with glutaraldehyde (final concentration $0.25 \%$ ). Cryotubes were vortexed and left 15 minutes in the dark at room temperature before freezing in liquid nitrogen. Samples were stored at $-80^{\circ} \mathrm{C}$ until analysis.

\subsubsection{HPLC pigment analysis}

Pigments were extracted from the polysulfone filter in a $95 \%$ methanol solution and were separated in a mobile phase gradient (methanol, acetonitrile, acetic acid and aqueous pyridine solution) through a Waters Symmetry®-C8 reversed-phase column and analysed through a 
diode array detector. These extraction and separation protocols, adapted from Zapata et al. (2000), were previously described in Stachowski-Haberkorn et al. (2009).

\section{Pigment fingerprinting}

Peaks were identified based on their retention time and absorption spectra compared with those of published pigment spectra (Jeffrey et al. 1997) and with those of pigment extracts prepared from clonal cultures with known pigment composition, obtained from the Roscoff Culture Collection (Vaulot et al. 2004): the dinoflagellate Amphidinium carterae (RCC88), the chlorophyte Dunaliella tertiolecta (RCC 6), the prymnesiophytes Emiliania huxleyi (RCC174), Pavlova lutheri (RCC180) and Phaeocystis globosa (RCC187), the chrysophyte Pelagococcus subviridis (RCC98), the diatom Skeletonema costatum (RCC70) and the cyanophyte Synechococcus sp. (RCC752). If "Pigment X" represents the pigment name, Pigment $\mathrm{X}$ ratio was defined as: pigment $\mathrm{X}$ area / sample-Chl $a$ area. The pigment fingerprint of a sample was defined as the set of all pigment ratios from this sample.

\section{The Chl a quantification}

$\mathrm{Chl} a$ concentration, measured at $440 \mathrm{~nm}$, was calibrated against a Chl $a$ standard solution (SIGMA, chlorophyll $a$ from spinach for HPLC Ref 10865), allowing calculation of Chl $a$ concentration in samples.

\subsubsection{Flow cytometry}

Samples were run using a FACSort flow cytometer equipped with a 488-nm argon laser and standard filter set-up (Becton Dickinson, San Jose, CA). Data were analysed using WinMDI v2.9 software (J. Trotter, http://facs.Scripps.edu/). Three populations of photosynthetic organisms were discriminated on the basis of their scatter signals and their natural red $(>630$ $\mathrm{nm})$ and orange fluorescence $(580 \pm 20 \mathrm{~nm})$, as described in Stachowski-Haberkorn et al. (2008).

\subsection{Statistical and principal component analysis of data}

Chl $a$ and flow cytometry data were first tested for homogeneity of variances (Bartlett's test) and normal distributions (Kolmogorov-Smirnov test). As several variables did not fulfil both conditions, a parametric analysis could not be used. Therefore, following the statistical procedures given in Sokal and Rohlf (1995), a Kruskal-Wallis test was used to check for significant differences in multiple treatment sets, and when the answer was positive a Mann- 
Whitney test was run for pairwise comparisons of medians. Statistical tests were performed using the Statgraphics® Plus v5.1 software.

Principal Component Analysis (PCA) of pigment fingerprints was performed using Statistica 8 software.

\section{Results}

\subsection{Experimental set-up}

The stainless-steel wheel supporting the microcosm bottles was easily hoisted manually onto the boat due to its seemingly low weight in water. After the wheel had been installed encircling the boat (Fig. 1), the whole structure was stable enough to allow bottle handling and the partial renewal of their contents. Microcosms were maintained out of the water for handling during approximately 15 minutes.

Work was only possible when the average wave height was less than 0.5 metres.

Such conditions are rarely exceeded in a protected bay, during the summer season. However, very rough conditions were observed on the day before the end of the experiment, when some bottles were lost.

\subsection{Microcosm assessment}

In natural surface water, Chl $a$ values (Fig. 2) decreased approximately 8-fold from day 0 to day 13.

In every microcosm, either control bottles or bottles with renewal, results on day 13 also showed a drastic Chl $a$ reduction (Fig. 2). This illustrates an important decrease in photosynthetic biomass over the period, both in microcosms and in the surrounding surface water.

Pigment fingerprints, obtained from HPLC analysis of microcosms and surface water, were analysed by PCA (Fig. 3).

Pigment fingerprint replicates within a group from surface water samples on the same day (day 0 , day 4 or day 13) showed close positions on the graph, but the three groups had distinctly separate positions. This illustrates the marked evolution of pigment fingerprints of the surface water over the period. After 13 days, the microcosms whose renewal was carried out with 25-, 50- or 200- $\mu \mathrm{m}$ filtered sea-water exhibited, an intermediate position (ellipse drawn in the centre) compared with those of natural surface water samples. Conversely, microcosms without renewal, or where renewal was made with water without living biomass (cut-off $0.22 \mu \mathrm{m}$ ), had values that were double those of any surface water sample (uppermost 
ellipse), suggesting in these microcosms a phytoplankton structure different from the surrounding waters over the period.

Analyses of these samples were also performed using flow cytometry. In surface water on the first day of the experiment, the detected phytoplankton cells (Fig. 4a) were mainly larger eukaryotes (about two thirds of the total cell count) followed by Prasinophytes, and then by a minority of Synechococcus. After four days, although the total cell count was maintained in the same range (Fig. 4b), a shift occurred in cell distribution, with the main cell population becoming the Prasinophytes. On day 13, this distribution pattern of relative abundances was maintained, but the total cell counts had dropped dramatically to a value about 3.5 times lower than on the first and fourth days of experiment (Fig. 4b). This decrease of larger cells (Prasinophytes + larger eukaryotes) observed throughout the experiment, is consistent with the concomitant Chl $a$ decrease (Fig. 2).

In microcosms, on the 13th day of the experiment, flow cytometry distribution patterns showed two trends:

- Control and $0.22 \mu \mathrm{m}$ microcosms were dominated by larger eukaryotes (more than two thirds of the total cell count), while Prasinophytes and Synechococcus both stood at values equal or lower than $20 \%$. These microcosms appeared different from any of the surface water samples or other microcosms, as the Prasinophyte counts in the samples were 4 to 5 times lower than the counts for larger eukaryotes.

- Microcosms with partial filtration at 25,50 and $200 \mu \mathrm{m}$ exhibited a pattern within the range of surface waters over the period: Synechococcus were lower than 30\%, Prasinophytes ranged from 30 to $60 \%$, and larger eukaryotes from 20 to $65 \%$.

Total counts in this second group of microcosms on day 13 were also at intermediate values compared with the surface water over the same period.

In these microcosms, total cell counts were significantly higher when filtration cut-off was reduced from 200 to 50 and $25 \mu \mathrm{m}$ (Fig. 4b; Spearman rank correlation $\mathrm{r}=-0.60$, p-value $=$ $0.016)$.

\subsection{Pesticide impact assessment}

\section{3.1 Bentazon}

Bentazon was added to the microcosms at 1,10 and $100 \mu \mathrm{g} \cdot \mathrm{L}^{-1}$ on the first day. Due to very rough weather conditions, this exposure experiment was terminated after 7 days. 
The final bentazon concentrations measured in the microcosms after 7 days were $0.76,5.67$, and $28.49 \mu \mathrm{g} . \mathrm{L}^{-1}$, respectively, while the expected remaining herbicide concentrations, calculated after 3 renewals, were $0.73,7.3$ and $73 \mu \mathrm{g} . \mathrm{L}^{-1}$, respectively.

After 7 days, no difference in Chl $a$ values was detected for any bentazon concentration compared with the control (data not shown).

Using PCA of the pigment fingerprints from microcosm replicates (Fig. 5), 4 groups could be detected that were related to the bentazon concentrations.

The 5 microcosms exposed to $1 \mu \mathrm{g} . \mathrm{L}^{-1}$ were positioned far from those of the 5 control microcosms. Furthermore, while the $10 \mu \mathrm{g} . \mathrm{L}^{-1}$ group was closer to the control group, the 100 $\mu \mathrm{g} . \mathrm{L}^{-1}$ microcosm replicates were localised mainly (3 out of 4 ) distant from the control. Such differences suggest a modification of the pigment fingerprints, starting at $1 \mu \mathrm{g} . \mathrm{L}^{-1}$ bentazon. A further data analysis of the pigment fingerprints from microcosms showed, for 10 pigments out of 17, a significant effect of the bentazon addition (Fig. 6). It must be noted that, although the $1 \mu \mathrm{g} . \mathrm{L}^{-1}$ and $10 \mu \mathrm{g} . \mathrm{L}^{-1}$ induced similar effects on the pigment ratios (of the 6 impacted pigments, 4 were simultaneously impacted), the $100 \mu \mathrm{g} . \mathrm{L}^{-1}$ treatment had a different impact: over the 5 impacted pigments for this concentration, only one was also impacted at $1 \mu \mathrm{g} . \mathrm{L}^{-1}$, and none were at $10 \mu \mathrm{g} \cdot \mathrm{L}^{-1}$.

Flow cytometry analysis (Fig. 7) also showed these significant differences for every exposed microcosm compared to the control. Furthermore, as for pigment analysis, flow cytometry revealed two kinds of impact, one at 1 and $10 \mu \mathrm{g} . \mathrm{L}^{-1}$, and the other at $100 \mu \mathrm{g} . \mathrm{L}^{-1}$. In both cases, among the three populations detected, only one was significantly impacted: the larger eukaryote abundance was reduced by $23 \%$ in $1 \mu \mathrm{g} . \mathrm{L}^{-1}$ and by $27 \%$ in $10 \mu \mathrm{g} . \mathrm{L}^{-1}$, while the Prasinophyte abundance was increased by $99 \%$ in $100 \mu \mathrm{g} . \mathrm{L}^{-1}$ microcosms.

\subsubsection{Dimethenamid:}

Dimethenamid was added to microcosms at 1,10 and $100 \mu \mathrm{g} . \mathrm{L}^{-1}$ on the first day. The final concentrations measured in microcosms after 12 days were $0.61,1.89$ and $23.17 \mu \mathrm{g} . \mathrm{L}^{-1}$, respectively, while expected remaining herbicide concentrations, calculated after 5 renewals, were $0.59,5.9$ and $59 \mu \mathrm{g} . \mathrm{L}^{-1}$, respectively.

After microcosms were exposed to dimethenamid for 12 days, Chl $a$ concentrations (Fig. 8) were significantly higher for all tested doses (p-value $<0.05$ Mann-Whitney). Furthermore, a significant positive correlation (Spearman rank: 0.76; p-value <0.05) was observed between dimethenamid and $\mathrm{Chl} a$ concentrations. 
Similarly, flow cytometry analysis (Fig. 9) showed a significant increase of $68 \%$ and $86 \%$ of

\section{Discussion \\ 4.1 Experimental set-up}

By running up to 108 independent microcosms, the experiment simultaneously tested multiple replicates of phytoplankton communities exposed to different molecules at different concentrations. The experiments, where three stainless-steel wheels were immersed and hoisted out of the water every other day, could be efficiently run by only two persons. However, working on a small $(3.9 \mathrm{~m})$ boat was quite challenging, and we would suggest, for routine ecotoxicological work, to use a larger boat equipped with a hoist. Before the work described here was performed, tests were carried out over the two previous summers. The total work conducted over these three summer seasons represents approximately one hundred immersion and hauling operations, and the wheels were maintained underwater for approximately 5 months per year over this 3 -year period, without significant problems except the impact due to bad weather during the last experiment. The material was installed in a bay open to northward wind and swell. A more protected area, which would also have offered the required 8-metre depth for mooring, was not available at working distance from the laboratory. Should a permanent experimental site be organised, the first selection criteria would be to use an area that was both deep and protected.

\subsection{Microcosm assessment}

Chl $a$ content of the surface water exhibited a marked decrease over the experimental period (Fig. 2), and flow cytometry analysis showed large decreases in total cell number, particularly the larger eukaryotes, over the same period (Fig. 4a, 4b). As the chlorophyll content is usually higher in larger cells and as the cell fraction larger than $20 \mu \mathrm{m}$ was not counted by flow cytometry, the total cell count cannot be directly related to the chlorophyll value. However the reductions observed in cell count could, at least partly, explain the Chl $a$ decrease observed. Such a reduction could be either due to the mixing or the displacement of the water masses by currents and tides, or to the evolution of the phytoplankton populations within the water column under physical and/or biological constraints (Cloern 1996; Pannard et al. 2008). 
Our goal was to maintain the phytoplankton community in microcosms as similar as possible to the natural community in surrounding waters over the experimental period.

On day 13, when no renewal or renewal only with cell-free water was made, the microcosms showed a drastic reduction in Prasinophyte/larger eukaryote ratios compared to natural waters or to other microcosms. It should be noted that these differences in ratio would be even higher, if the comparison was based on the (more ecologically significant) cumulative cell surface or cell volume of each population. The PCA of pigment fingerprints also suggested that populations of these microcosms were different from surface water samples. In the $0.22 \mu \mathrm{m}$ microcosms, the water renewal, using cell-free water, diluted the populations compared with the control microcosms. Its effect can be estimated to reduce the cell counts by $47 \%$ over the experiment ( 6 times at a $10 \%$ rate). However, the total cell count remained slightly higher in these microcosms than in the control. This result suggests that cell-free water addition could help to maintain the phytoplankton population. It must be noted that if cells were not discarded during the water renewal process, the calculated cell densities in these $0.22 \mu \mathrm{m}$ microcosms would be almost doubled, and would then be in the same range as in the other renewal microcosms.

Chlorophyll $a$ and total cell counts decreased in microcosms over the 13-day period.

A first cause could be, as hypothesized for the natural surrounding waters, a change in physical environmental conditions (light, temperature, etc) that would modify the fate of populations subject to growth, death and grazing.

Second, previous studies have demonstrated that in phytoplankton communities, the reduction of the biodiversity induces a reduction of biomass productivity (Ptacnik et al. 2008, Striebel et al. 2009). This could possibly apply here, especially to the NR and $0.22 \mu \mathrm{m}$ microcosms. In these enclosed environments, specific individuals could be grazed or destroyed, and the lack of cell addition through renewal process could induce a reduction in the community diversity. The dramatic changes in population ratios observed here may be related to such a reduction in diversity. A subsequent reduction in productivity could occur, and the populations would then be reduced.

From these experiments, we showed that microcosms without renewal, or the use of cell-free sea water for renewal, did not fulfil our objective of a phytoplankton community, whose composition would be close to the natural surrounding environment: The cell ratio was not representative of natural surrounding waters.

When 25-, 50- or 200- $\mu \mathrm{m}$ filtered waters were added, the distribution of populations after 13 days exhibited an intermediate pattern when compared to surface waters over the period. 
Furthermore, PCA on pigment fingerprints showed these microcosms as intermediate partial renewal to maintain the phytoplankton community similar to the natural surrounding one.

Such results are also consistent with our previous work (Stachowski-Haberkorn et al. 2009), which demonstrated similar diversity indices, a similar number of species, and the same three major groups in communities in $200-\mu \mathrm{m}$ filtered microcosms and the surrounding surface waters.

Present results also showed a relationship between the reduction of the filtration cut-off (200, 50 , and $25 \mu \mathrm{m}$ ) of the renewal water, and the increase of the total cell populations. We hypothesize that such a reduction in filtration cut-off may induce a reduction in the microzooplankton content (smaller than $200 \mu \mathrm{m}$ ): this could induce a reduction of the grazing pressure, and thus an increase of the phytoplankton populations in these microcosms. Such high grazing pressure of microzooplankton on the $<20 \mu \mathrm{m}$ phytoplankton fraction has already been reported (Gifford at al. 1995). Similar cell density increases were also observed in experiments where the grazing pressure was reduced by dilution (Landry et al. 1993). Therefore, in order to maintain the top-down control of phytoplankton populations by grazers in microcosms at levels close to those of the surrounding waters, we must avoid reducing the grazer population when performing water renewal. This can be done by using water supply subjected to only a large filtration cut-off, thus allowing the phytoplankton community in microcosms to be similar to the natural surrounding waters. As total cell count is still higher in microcosms than in natural surrounding waters, even in $200-\mu \mathrm{m}$ filtered microcosms, a higher filtration cut-off should be tested that could possibly mimic the natural conditions better.

These experiments suggest that the positive role of renewal in maintaining a close-to-natural phytoplankton community is mainly due to the inoculation of fresh grazers and cells. Thus, we can hypothesize that, in microcosms where renewal is omitted, microzooplankton is rapidly destroyed: because these organisms cannot operate their daily vertical migration, they could be affected by light conditions during the day.

As this could then induce a reduction of the grazing pressure on larger eukaryotes, these possibly mixotrophic cells could increase their competitive and grazing pressure on smaller Prasinophytes and Synechococcus. 


\subsection{Herbicide impact assessment}

When bentazon or dimethenamid were added at $1 \mu \mathrm{g} . \mathrm{L}^{-1}$, the concentrations detected at the end of the experiment were close to the expected values for both herbicides. The detected concentrations for $10 \mu \mathrm{g} . \mathrm{L}^{-1}$ herbicide treatments were lower than expected. For the $100 \mu \mathrm{g}$. $\mathrm{L}^{-1}$ treatments, the were less than half the expected value for the $100 \mu \mathrm{g} . \mathrm{L}^{-1}$ This could be due to the possible adsorption/desorption during the dilution process, on bottle walls and/or on the organic matter present in seawater. Such losses are consistent with previous data obtained in the same kind of experiments (Stachowski-Haberkorn et al. 2009) and were also reported by Damiens et al. (2004). Pesticide concentrations encountered in estuarine areas are usually below $1 \mu$ g.L ${ }^{-1}$ (Lehotay et al. 1998; Oros et al. 2003; Steen et al. 2001). However, for example, a glyphosate concentration of $1.2 \mu \mathrm{g} . \mathrm{L}^{-1}$ was detected in Marennes-Oléron bay over an 11-day period (Burgeot et al. 2007), and analyses performed by IDHESA Laboratory (Brest, France) reported maximal concentrations of $0.41 \mu \mathrm{g} . \mathrm{L}^{-1}$ for glyphosate and $0.64 \mu \mathrm{g} . \mathrm{L}^{-}$ ${ }^{1}$ for its degradation product, AMPA, in the Bay of Brest (Gaël Durand, pers. comm.). We can therefore consider the lowest concentration tested here likely to be representative of peak pollution in coastal areas.

\subsubsection{Bentazon}

Flow cytometry analysis showed a significant reduction in the larger eukaryote counts for the lowest tested concentration of $1 \mu \mathrm{g} . \mathrm{L}^{-1}$. This impact is confirmed by a modification of the pigment fingerprints, demonstrated using both PCA and pigment ratio comparison. The same effects on larger eukaryotes and pigment ratios were observed for $10 \mu \mathrm{g} . \mathrm{L}^{-1}$ treatments. At $100 \mu \mathrm{g} . \mathrm{L}^{-1}$ exposure, however, a different impact was observed on cell counts and on pigment ratio, and on the PCA graph (Fig. 5).

Such results show that the modification of the phytoplankton community structure differs depending on the pesticide concentration. We may hypothesize that, the larger eukaryote population was impacted at 1 and $10 \mu \mathrm{g} . \mathrm{L}^{-1}$ herbicide concentrations, but that increased concentration $\left(100 \mu \mathrm{g} . \mathrm{L}^{-1}\right)$ could impact the grazers of Prasinophytes and larger eukaryotes, thus offsetting the direct effect on larger eukaryotes and inducing the increase in Prasinophytes cell counts.

\subsubsection{Dimethenamid}


When exposed to $1 \mu \mathrm{g} . \mathrm{L}^{-1}$ dimethenamid for 12 days, only Chl $a$ exhibited a significant increase. The $10 \mu \mathrm{g} . \mathrm{L}^{-1}$ and $100 \mu \mathrm{g} . \mathrm{L}^{-1}$ doses induced increases in both $\mathrm{Chl} a$ content and larger eukaryote counts, with significant dose-correlation. These positive dose-correlations, suggest that grazers could be the impacted population, inducing an increase of the photosynthetic community by reduction of the grazing rate. However, compared to bentazon, whose impact was stronger, even though it was added over a shorter 7-day period, these results suggest that the phytoplankton community could be less sensitive to dimethenamid.

\section{Conclusion}

Microcosms attached to immersed structures allow enclosed phytoplankton communities to be exposed to natural light and temperature conditions. A recurrent partial renewal, by addition of natural, cell-containing water obtained through high cut-off filtration, was required to maintain the characteristics of the phytoplankton community close to those of the surrounding environment. Further work is needed to confirm the putative role of grazers in such microcosms, and to test the effects of higher filtration cut-off, and other renewal frequencies. Both bentazon and dimethenamid induced modifications of the phytoplankton community starting at $1 \mu \mathrm{g} . \mathrm{L}^{-1}$, the lowest tested concentration. This suggests that these pesticides could impact phytoplankton communities in polluted coastal areas.

The populations directly or indirectly impacted differ depending on the dose and herbicide molecule tested. This illustrates the diversity of targets concerned by phytoplankton toxicity, and thus the advantage of using microcosms, rather than monospecific cultures, for environmental toxicity assessments. Further experiments are still needed to investigate the mechanisms involved on zooplankton and/or phytoplankton herbicide toxicity. The equipment presented here allows a large set of these microcosms to be run efficiently and simultaneously, for periods up to two weeks. This makes it an efficient tool for impact assessments of multiple chemical compounds on phytoplankton communities in "close-tonatural" conditions, over ecologically realistic periods.

\section{Acknowledgments}

We wish to thank the Ministère de l'Ecologie, du Développement Durable et le l'Energie, and the Région Bretagne, who provided the funding for this research. We also thank Patrick Lechevalier for diving work, the "Capitainerie de Beg-Meil", city of Fouesnant, Patrick Le 
Coz and Yann le Floch for their technical assistance in the field, Gaël Durand for pesticide analysis, and Louis Quiniou and Hansy Haberkorn for advice on data treatment.

\section{References}

Añasco, N., Koyama, J., Uno, S., 2010. Pesticide Residues in Coastal Waters Affected by Rice Paddy Effluents Temporarily Stored in a Wastewater Reservoir in Southern Japan. Arch. Environ. Contam. Toxicol. 58, 352-360.

Barry, M.J., Logan, D.C., 1998. The use of temporary pond microcosms for aquatic toxicity testing: direct and indirect effects of endosulfan on community structure.

Aquat. Toxicol. 41, 101-124.

Bérard, A., Leboulanger, C., Pelte, T., 1999. Tolerance of Oscillatoria limnetica 
Lemmermann to Atrazine in Natural Phytoplankton Populations and in Pure Culture:

Influence of Season and Temperature. Arch. Environ. Contam. Toxicol. 37, 472-479.

Burgeot, T., Gagnaire, B., Renault, T., Haure, J., Moraga, D., David, E., Boutet, I., Sauriau, P.G., Malet, N., Bouchet, V., Le Roux, A., Lapègue, S., Bouilly, K., Le Moullac, G., Arzul, G., Knoery, J., Quiniou, F., Bacher, C., Soletchnik, P., 2007. Summer mortality of Pacific oyster Crassostrea gigas. The Morest Project. Samain, J.F, McCombie, H. (eds). Ed. Ifremer/Quæ, Versailles, France, pp. 107-151.

Cairns, J.J., 1986. The myth of the most sensitive species. Bioscience 36, 670-672.

Chesworth, J.C., Donkin, M.E., Brown, M.T., 2004. The interactive effects of the antifouling herbicides Irgarol 1051 and Diuron on the seagrass Zostera marina (L.). Aquat. Toxicol. 66, 293-305.

Cloern, J.E., 1996. Phytoplankton bloom dynamics in coastal ecosystems: a review with some general lessons from sustained investigation of San Francisco Bay, California. Rev. Geophys. 34, 127-168.

Damiens, G., His, E., Gnassia-Barelli, M., Quiniou, F., Romeo, M., 2004. Evaluation of biomarkers in oyster larvae in natural and polluted conditions. Comp. Biochem. Physiol. $138 \mathrm{C}(2), 121-128$.

de la Broise, D., Palenik, B., 2007. Immersed in situ microcosms: A tool for the assessment of pollution impact on phytoplankton. J. Exp. Mar. Biol. Ecol. 341, 274-281.

DeLorenzo, M.E., Lauth, J., Pennington, P.L., Scott, G.I., Ross, P.E., 1999. Atrazine effects on the microbial food web in tidal creek mesocosms. Aquat. Toxicol. 46, 241-251.

DeLorenzo, M.E., Scott, G.I., Ross, P.E. 2001. Toxicity of pesticides to aquatic microorganisms: a review. Environ. Toxicol. Chem. 20, 84-98.

DeLorenzo, M.E., Leatherbury, M., Weiner, J.A., Lewitus, A.J., Fulton, M.H., 2004. Physiological factors contributing to the species-specific sensitivity of four estuarine microalgal species exposed to the herbicide atrazine. Aquat. Ecosyst. Health Manage. 7, 137-146.

Devilla, R.A., Brown, M.T., Donkin, M., Readman, J.W., 2005. The effects of a PSII inhibitor on phytoplankton community structure as assessed by HPLC pigment analyses, microscopy and flow cytometry. Aquat. Toxicol. 71,25-38.

Dorigo, U., Bourrain, X., Berard, A., Leboulanger, C., 2004. Seasonal changes in the sensitivity of river microalgae to atrazine and isoproturon along a contamination gradient. Sci. Total. Environ. 318, 101-114.

Galhano, V., Peixoto. F., Gomes-Laranjo, J., Fernández-Valiente, E., 2009. Differential 
Effects of bentazon and Molinate on Anabaena cylindrica, an Autochthonous

Gatidou, G., Thomaidis, N.S., 2007. Evaluation of single and joint toxic effects of two antifouling biocides, their main metabolites and copper using phytoplankton bioassays. Aquat. Toxicol. 85, 184-191.

Gifford, D.J.,Fessenden, L.M.,Garrahan, P.R., Martin E., 1995 Grazing by microzooplankton and mesozooplankton in the high-latitude North Atlantic Ocean: spring versus summer dynamics. J. Geophys.Res. 100, 6665-6675.

Jeffrey, S.W., Mantoura, R.F.C., Bjørnland, T., 1997. Data for the identification of 47 key phytoplankton pigments. In: Jeffrey, S.W., Mantoura, R.F.C., Wright, S.W. (Eds), Phytoplankton pigments in oceanography UNESCO, Paris, pp. 447-559.

Kostanjšek, R., Lapanje, A., Drobne, D., Nikcevic, S., Perovic, A., Zidar, P., Štrus, J., Hollert, H., Karaman, G., 2005. Bacterial Community Structure Analyses to Assess Pollution of Water and Sediments in the Lake Shkodra/Skadar, Balkan Peninsula. Environ. Sci. \& Pollut. Res. 12, 361-368.

Lage, O.M., Sansonetty, F., O’Connor, J.E., Parente, A.M., 2001. Flow cytometric analysis of chronic and acute toxicity of copper(II) on the marine dinoflagellate Amphidinium carterae. Cytometry 44, 226-235.

Landry, M.R., Gifford, D.J., Kirchman, D.L., Wheeler, P.A., Monger, B.C., 1993. Pelagic Ecodynamics in the Gulf of Alaska. Results from the SUPER Program. Prog. Oceanogr. 32, 239-258.

Landry, M.R., Hassett, R.P., 1982. Estimating the grazing impact of marine microzooplankton. Mar. Biol. 67, 283-288.

Leboulanger, C., Rimet, F., Hème de Lacotte, M., Bérard, A., 2001. Effects of atrazine and nicosulfuron on freshwater microalgae. Environ. Int. 26, 131-135.

Lehotay, S.J., Harman-Fetcho, J.A., McConnell, L.L., 1998. Agricultural pesticide residues in oysters and water from two Chesapeake bay tributaries. Mar. Pollut. Bull. 37, 32-44.

Lewis, S.E., Brodie, J.E., Bainbridge, Z.T., Rohde, K.W., Davis, A.M., Masters, B.L., Maughan, M., Devlin, M.J., Mueller, J.F., Schaffelke, B., 2009. Herbicides: A new threat to the Great Barrier Reef. Environ. Pollut. 157, 2470-2484.

Magnusson, M., Heimann, K., Quayle, P., Negri, A.P., 2010. Additive toxicity of herbicide mixtures and comparative sensitivity of tropical benthic microalgae. Mar. Pollut. Bull. 60, 1978-1987. 
Marie, D., Brussaard, C., Partensky, F., Vaulot, D., 1999. Flow cytometric analysis of phytoplankton, bacteria and viruses. In: Current Protocols in Cytometry. John Wiley \& Sons, Inc. 11.11.1-11.11.15.

Oros, D.R., Jarman, W.M., Lowe, T., David, N., Lowe, S., Davis, J.A., 2003. Surveillance for previously unmonitored organic contaminants in the San Francisco estuary. Mar. Pollut. Bull. 46, 1102-1110.

Pannard, A., Claquin, P., Klein, C., Le Roy, B., Véron, B., 2008. Short-term variability of the phytoplankton community in coastal ecosystem in response to physical and chemical conditions changes. Estuar. Coast. Shelf. Sci. 80, 212-224.

Pesce, S., Fajon, C., Bardot, C., Bonnemoy, F., Portelli, C., Bohatier, J., 2008. Longitudinal changes in microbial planktonic communities of a French river in relation to pesticide and nutrient inputs. Aquat. Toxicol. 86, 352-360.

Prado, R., García, R., Rioboo, C., Herrero, C., Abalde, J., Cid, A. 2009. Comparison of the sensitivity of different toxicity test endpoints in a microalga exposed to the herbicide paraquat. Environ. Int. 35, 240-247.

Ptacnik, R., Solimini, A.G., Andersen, T., Tamminen, T., Brettum, P., Lepisto, L., Willen, E., Rekolainen, S., 2008. Diversity predicts stability and resource use efficiency in natural phytoplankton communities. Proc. Nat. Acad. Sci. USA 105, 5134-5138.

Readman, J.W., Devilla, R.A., Tarran, G., Llewellyn, C.A., Fileman, T.W., Easton, A., Burkill, P.H., Mantoura, R.F.C., 2004. Flow cytometry and pigment analyses as tools to investigate the toxicity of herbicides to natural phytoplankton communities. Mar. Environ. Res. 58, 353-358.

Rioboo, C., Gonzalez, O., Herrero, C., Cid, A., 2002. Physiological response of freshwater microalga ( $\underline{\text { Chlorella vulgaris }}$ ) to triazine and phenylurea herbicides. Aquat. Toxicol. 59, 225-235.

Rutten, T.P.A., Sandee, B., Hofman, A.R.T., 2005. Phytoplankton monitoring by high performance flow cytometry: A successful approach? Cytom. Part A 64A, 16-26.

Santin-Montanya, I., Sandin-Espana, P., Garcia Baudin, J.M., Coll-Morales, J., 2007. Optimal growth of Dunaliella primolecta in axenic conditions to assay herbicides. Chemosphere 66, 1315-1322.

Seguin, F., Leboulanger, C., Rimet, F., Druart, J.C., Bérard, A., 2001. Effects of atrazine and nicosulfuron on phytoplankton in systems of increasing complexity. Arch. Environ. Contam. Toxicol. 40, 198-208. 
Sherrard, N.J., Nimmo, M., Llewellyn, C.A., 2006. Combining HPLC pigment markers and ecological similarity indices to assess phytoplankton community structure: An environmental tool for eutrophication? Sci. Total. Environ. 361, 97-110.

Sokal, R.R., Rohlf, F.J., 1995. Biometry: the principles and practice of statistics in biological research. 3rd edition. W.H. Freeman and Co, New York.

Stachowski-Haberkorn, S., Beker, B., Marie, D., Haberkorn, H., Coroller, L., de la Broise, D., 2008. Impact of Roundup on the marine microbial community, as shown by an in situ microcosm experiment. Aquat. Toxicol. 89, 232-241.

Stachowski-Haberkorn, S., Beker, B., Marie, D., Haberkorn, H., Quiniou, L., de la Broise, D., 2009. Comparative study of three analysis methods (TTGE, flow cytometry and HPLC) for xenobiotic impact assessment on phytoplankton communities. Ecotoxicology, 18, 364-376.

Stauber, J., Adams, M., 2005. Microalgal toxicity tests using flow cytometry. Small-Scale Freshwater Toxicity Investigations 1:203-241

Steen, R.J.C.A., van der Vart, J., Hiep, M., Van Hattum, B., Cofino, W.P., Brinkman, U.A.T., 2001. Gross fluxes and estuarine behaviour of pesticides in the Scheldt Estuary (19951997) Environ. Pollut. 115, 65-79.

Striebel, M., Behl, S., Diehl, S., Stibor, H., 2009. Spectral Niche Complementarity and Carbon Dynamics in Pelagic Ecosystems. Am. Nat. 174, 141-147.

Van den Brink, P.J., Hartgers, E.M., Gylstra, R., Bransen, F., Brock, T.C.M., 2002. Effects of a Mixture of Two Insecticides in Freshwater Microcosms: II. Responses of Plankton and Ecological Risk Assessment. Ecotoxicology 11, 181-197.

Vaulot, D., Le Gall, F., Marie, D., Guillou, L., Partensky, F., 2004. The Roscoff Culture Collection (RCC): a collection dedicated to marine picoplankton. Nova Hedwigia 79, 49-70.

Weiner, J.A., DeLorenzo, M.E., Fulton, M.H., 2004. Relationship between uptake capacity and differential toxicity of the herbicide atrazine in selected microalgal species. Aquat. Toxicol. 68, 121-128.

Yasuno, M., Asaka, A., Kono, Y., 1993. Effects of pyraclofos (an organophosphorus insecticide) on nutrient enriched ecosystems. Chemosphere 27, 1813-1824.

Yu, Y., Kong, F., Wang, M., Qian, L., Shi, X., 2007. Determination of short-term copper toxicity in a multispecies microalgal population using flow cytometry. Ecotox. Environ. Safe. 66, 49-56.

Zamora-Ley, I.M., Gardinali, P.R., Jochem, F.J., 2006. Assessing the effects of Irgarol 1051 
on marine phytoplankton populations in Key Largo Harbor, Florida. Mar. Pollut. Bull. $52,935-941$.

Zapata, M., Rodríguez, F., Garrido, J.L., 2000. Separation of chlorophylls and carotenoids from marine phytoplankton: a new HPLC method using a reversed phase C8 column and pyridine-containing mobile phases. Mar. Ecol. Prog. Ser. 195, 29-45. 
Figure 1: Partial view of the microcosm support frame, shown hoisted out of the water as for partial microcosm renewal.

Figure 2: Chlorophyll $a$ in surrounding surface water during the experiment and in microcosms after 13 days. Renewal water was prepared from surface water filtered through $0.2,25,50$, or $200 \mu \mathrm{m}$ mesh. Vertically-aligned crosses represent replicates. Shared letters show where there is no significant difference (Mann-Whitney test).

Figure 3: PCA of pigment fingerprint data from microcosms and surface water samples. d0, d4, d13: replicate samples from surface water on day 0 , day 4, and day 13, respectively. $\mathbf{0 . 2 2}, \mathbf{2 5}, \mathbf{5 0 , 2 0 0}$ : samples from microcosm replicates subjected to $10 \%$ water renewal every other day with water filtered through $0.2,25,50$, or $200 \mu \mathrm{m}$ filters, respectively.

NR: microcosm replicates with no water renewal.

Figure 4: Flow cytometry analysis of samples from surface water during the experiment and from microcosms after 13 days. Bars and dots represent the mean of 4 or 5 microcosm analyses, error bars represent standard errors.

A: Cell count distribution of populations

B: Total cell count.

Figure 5: PCA of pigment fingerprint data sets (17 pigments) from microcosms exposed to bentazon for 7 days. Each dot represents a treatment replicate.

0: no bentazon; 1: $1 \mu \mathrm{g} / \mathrm{L}$ bentazon; 10: $10 \mu \mathrm{g} / \mathrm{L}$ bentazon; 100: $100 \mu \mathrm{g} / \mathrm{L}$ bentazon.

Figure 6: Pigment ratio from HPLC analyses, in microcosms exposed to bentazon for 7 days. Only pigments in which differences were detected are shown (17 pigments analysed).

Bars represent the average of 4 or 5 microcosm analyses, error bars represent standard errors. *: significant difference ( $<<0.05$; Mann-Whitney) compared with $0 \mu \mathrm{g} / \mathrm{L}$.

Figure 7: Cell count distribution from flow cytometry analysis in microcosms exposed to bentazon for 7 days. Bars represent the mean of 4 or 5 microcosm analyses, error bars represent standard errors.

*: significant difference ( $\mathrm{p}<0.05$; Mann-Whitney) compared with $0 \mu \mathrm{g} / \mathrm{L}$.

Figure 8: Chlorophyll $a$ in microcosms exposed to dimethenamid for 12 days. Vertically aligned dots represent replicates.

Figure 9: Cell count distribution from flow cytometry analysis in microcosms exposed to dimethenamid for 12 days. Bars represent the mean of 4 or 5 microcosm analyses, error bars represent standard errors.

*: significant difference ( $<<0.05$; Mann-Whitney) compared with $0 \mu \mathrm{g} / \mathrm{L}$.

Figure 10: PCA of pigment fingerprint data sets (17 pigments) from microcosms exposed to dimethenamid, for 12 days. Each dot represents a treatment replicate.

0: no dimethenamid; 1: $1 \mu \mathrm{g} / \mathrm{L}$ dimethenamid; 10: $10 \mu \mathrm{g} / \mathrm{L}$ dimethenamid; 100: $100 \mu \mathrm{g} / \mathrm{L}$ dimethenamid. 


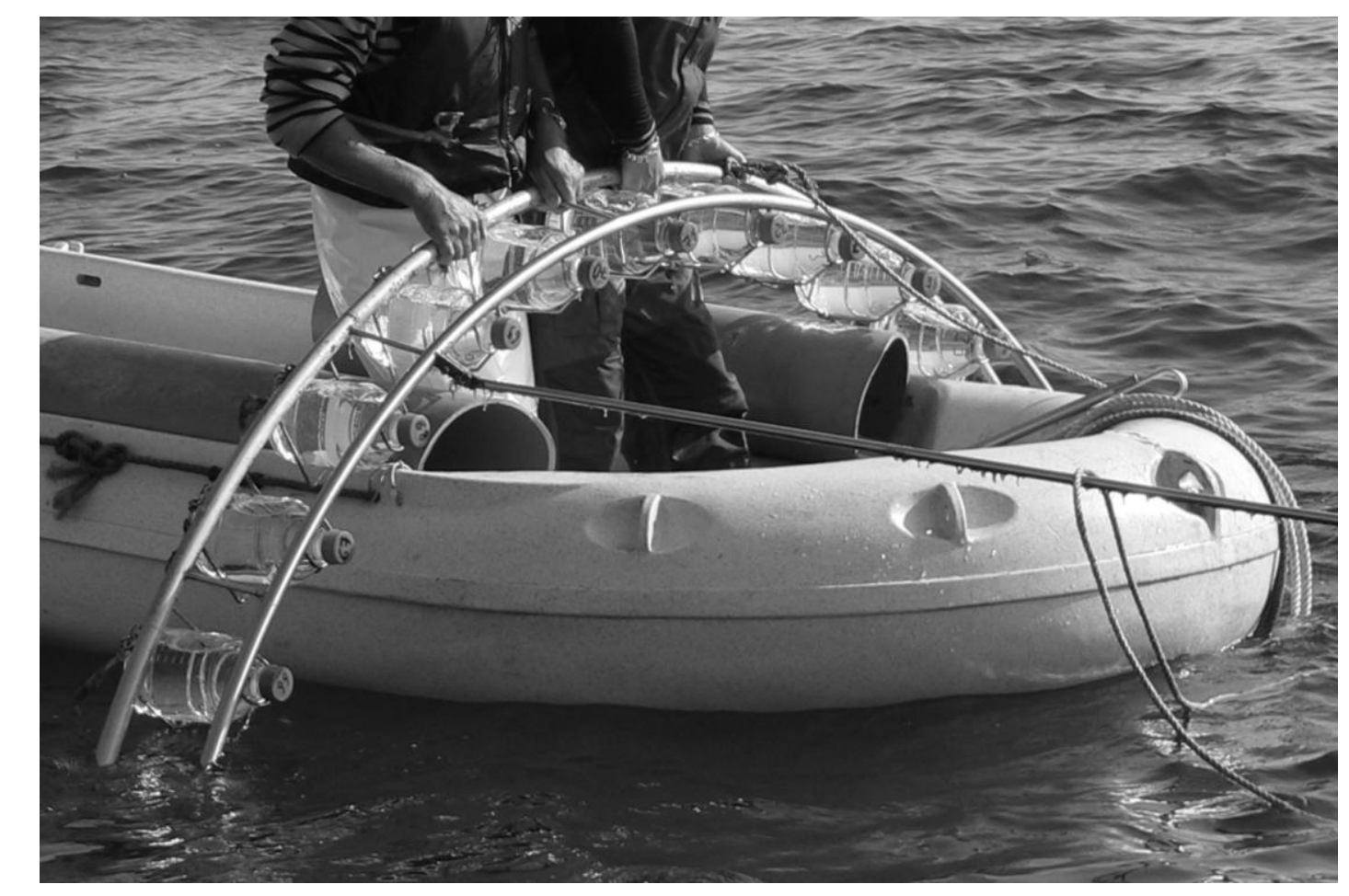

Figure 1 
Figure(s)

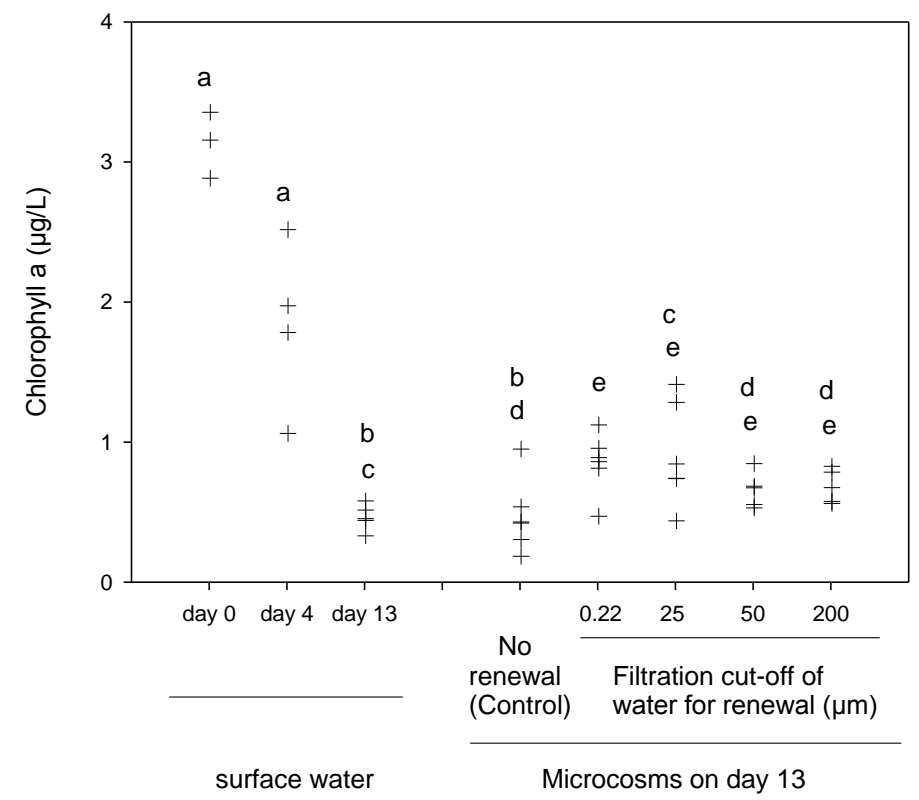

Figure 2 


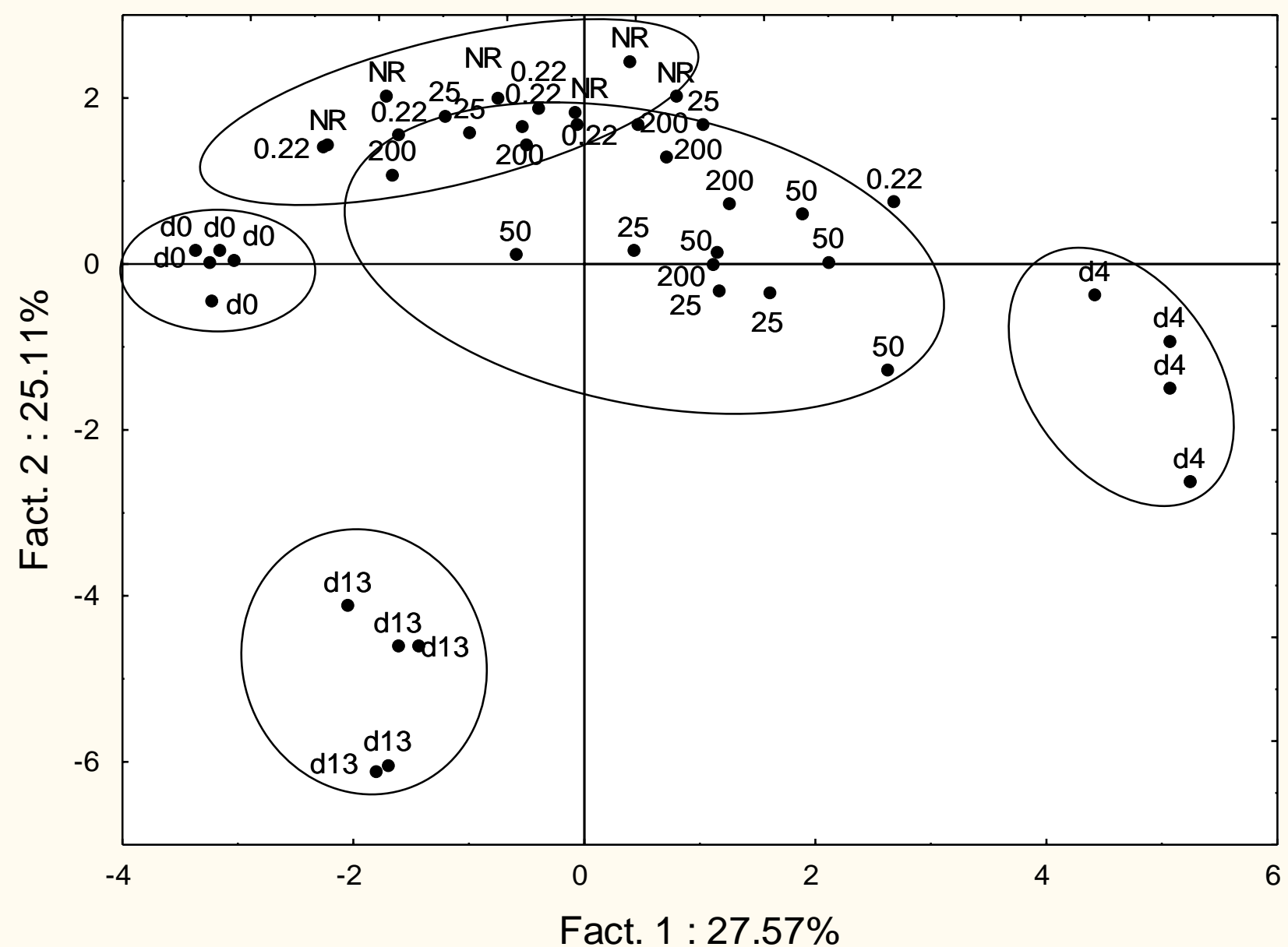

Figure 3 


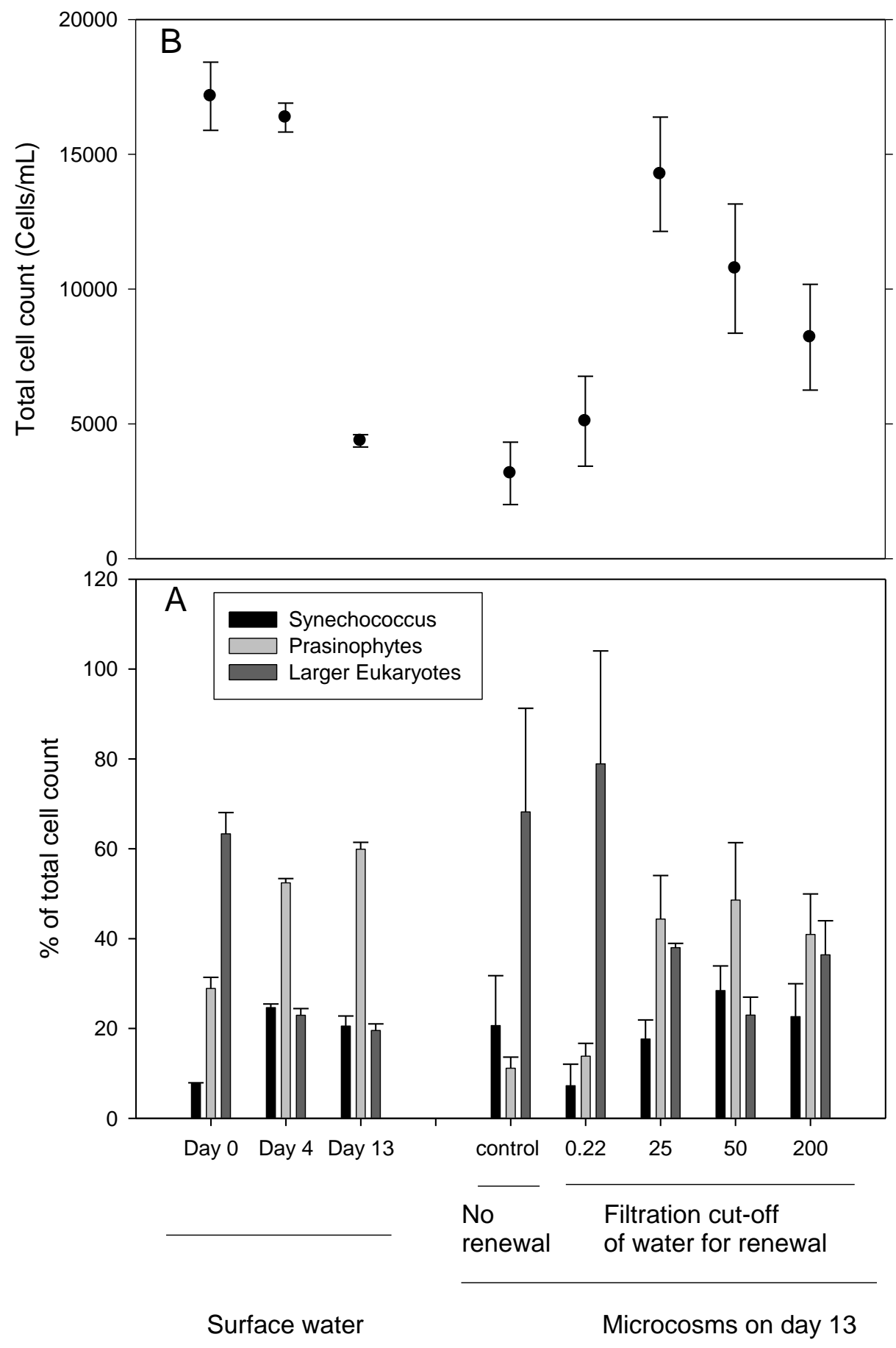

Figure 4 


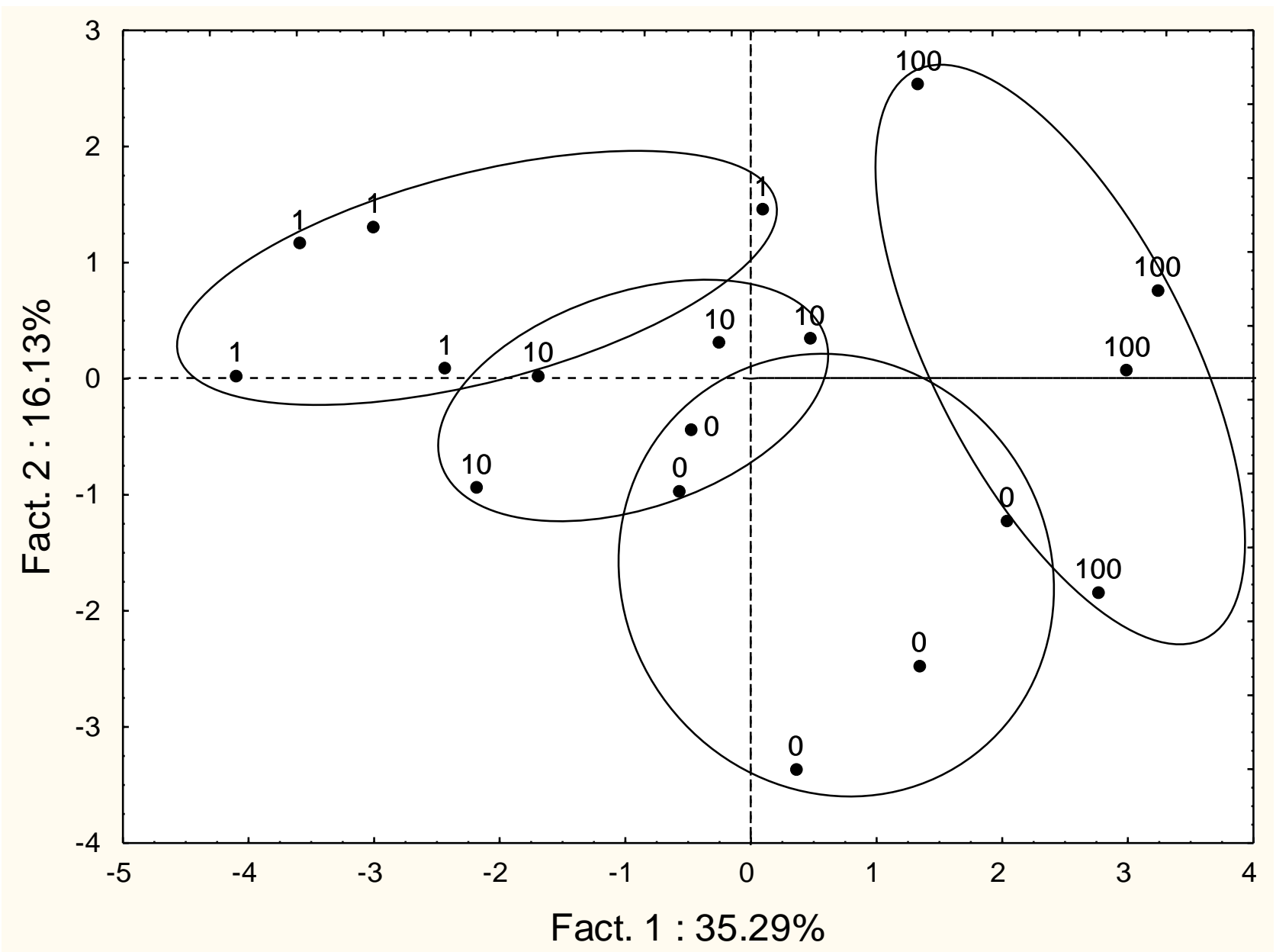

Figure 5 


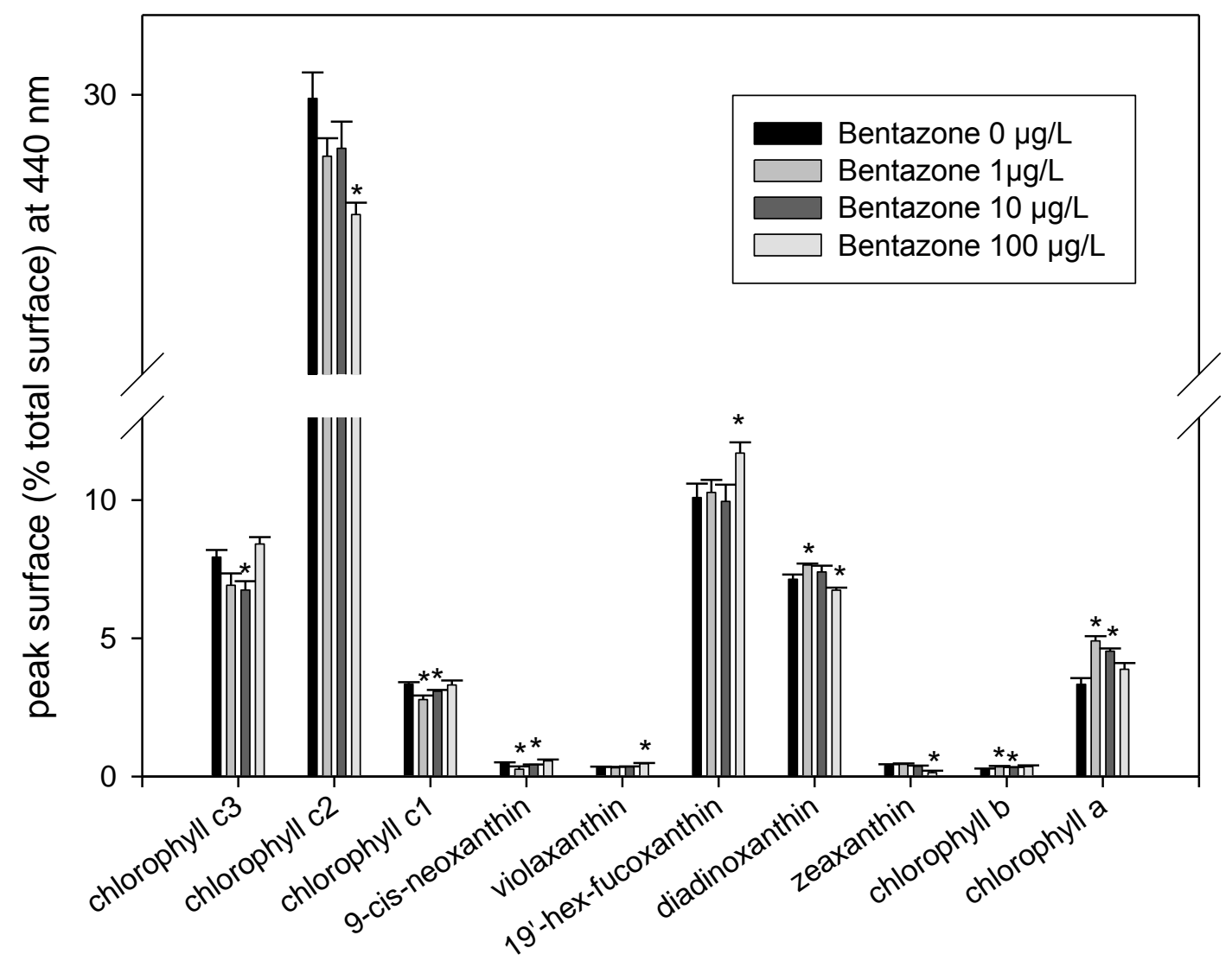

Figure 6 


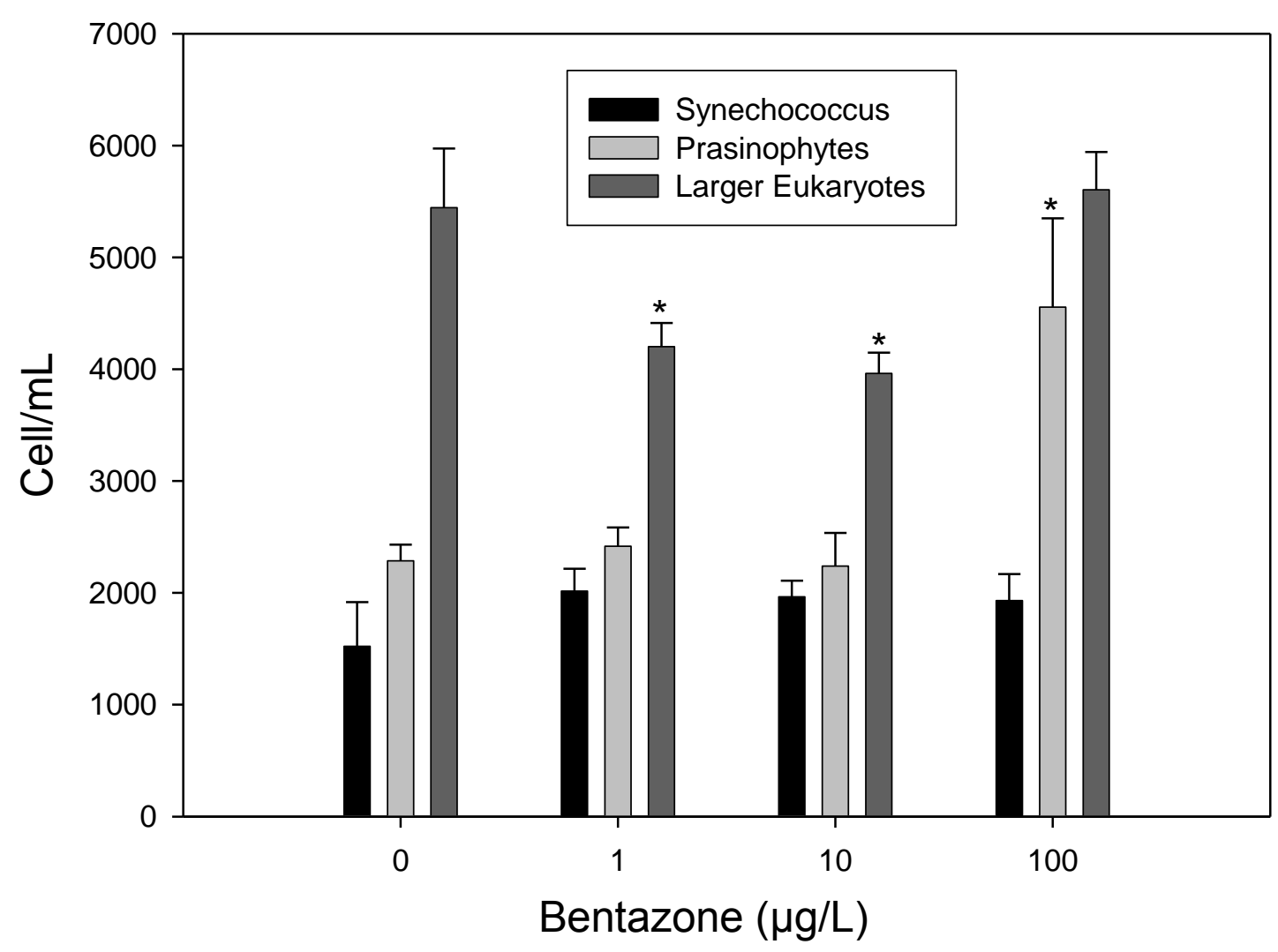

Figure 7 


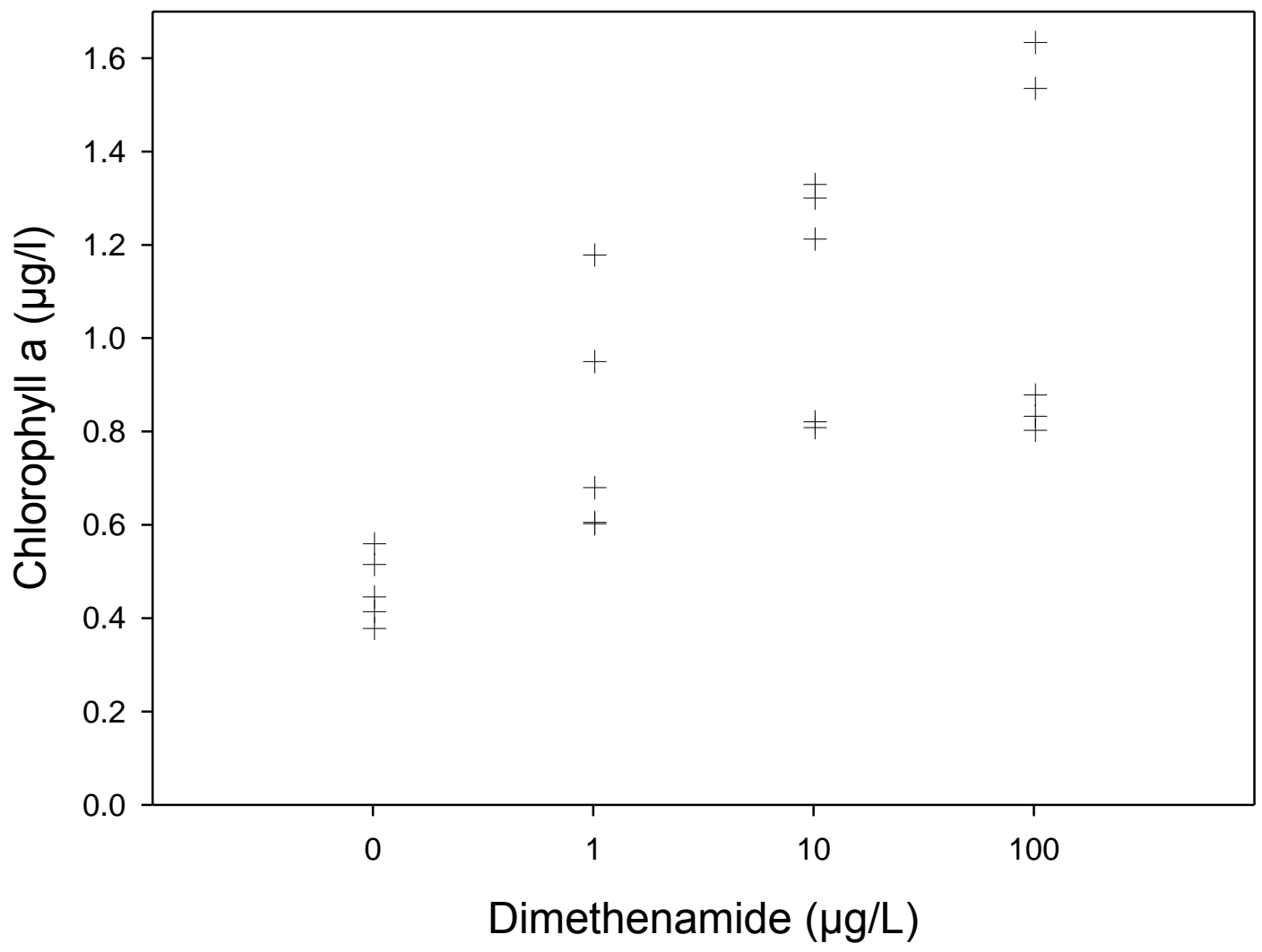

Figure 8 


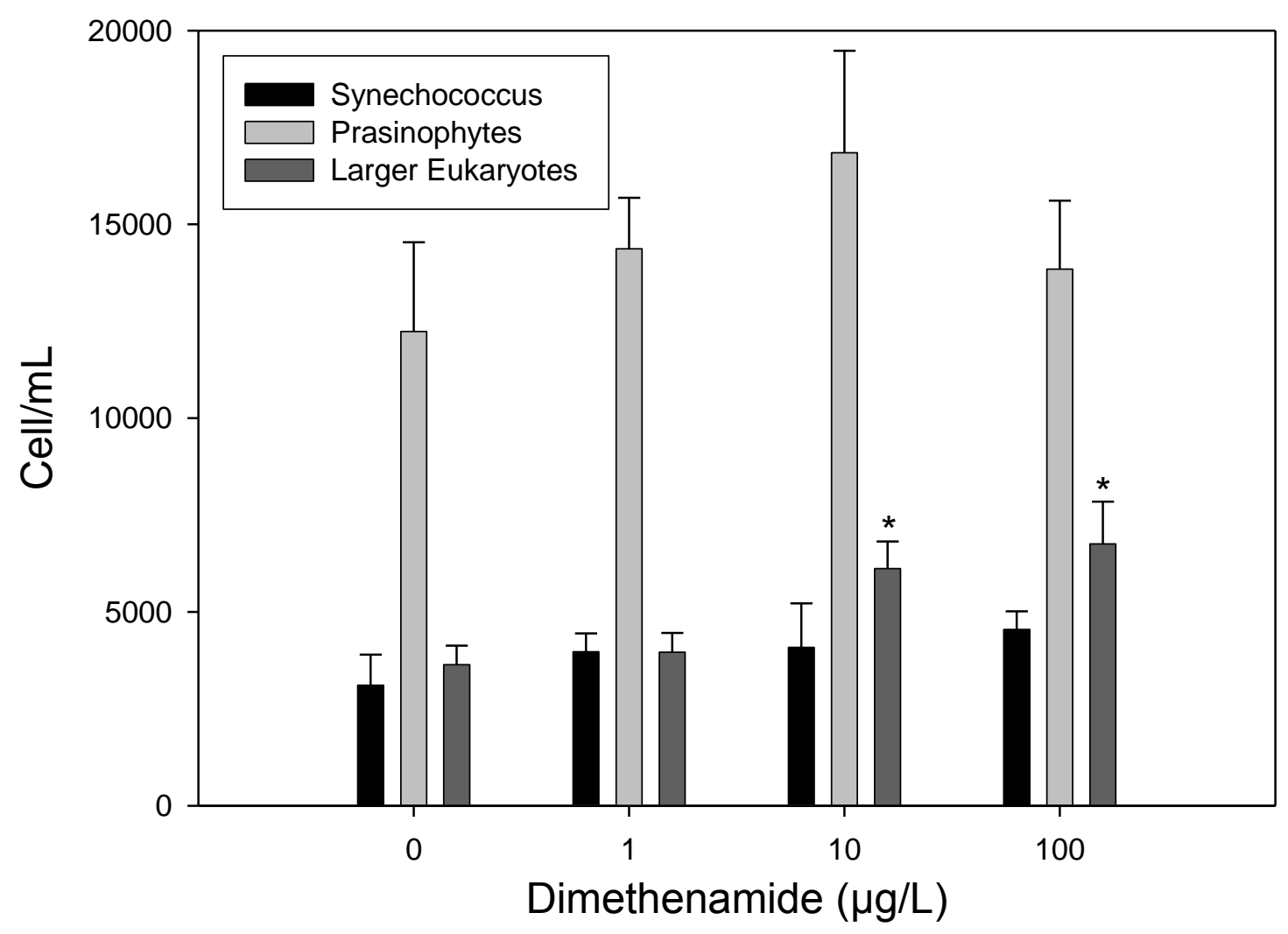

Figure 9 


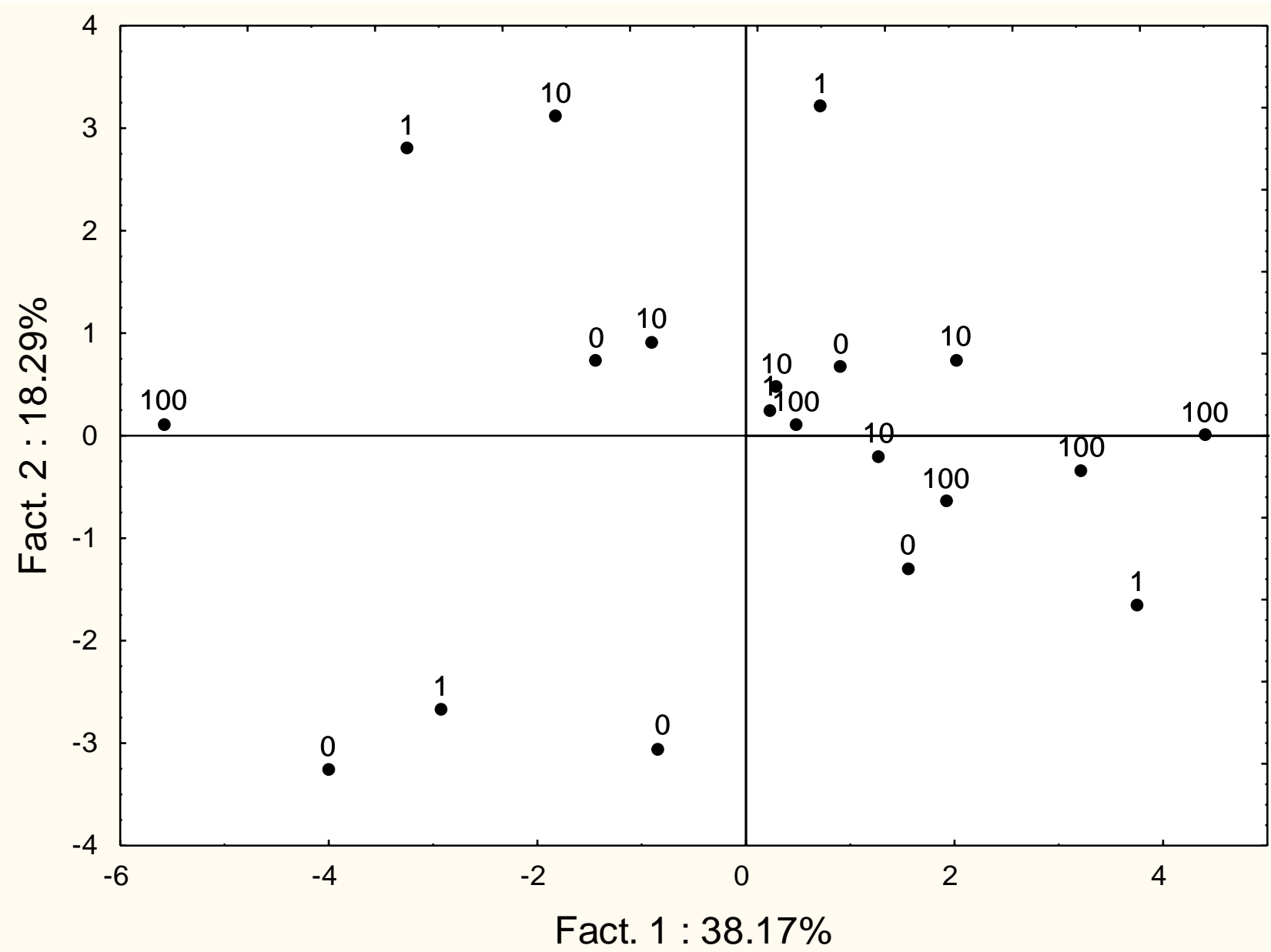

Figure 10 